\title{
Penggunaan Teknik Dictogloss Untuk Meningkatkan Kemampuan Mendengarkan Siswa
}

\author{
Elly Handajani \\ SMKN 3 Kota Sorong \\ Email: ellyhandajani@gmail.com
}

\begin{abstract}
Listening is a basic skill that is very important to master and support other skills such as speaking, reading and writing. The aim of this study was to find out whether or not teaching listening by using dictogloss technique can improve the students' listening skill. The subject of this study was the second class of SMKN 3 Sorong, class XI OD were 22 students. This study was a classroom action research within two cycles. The data collection techniques were (1) observation sheet which was applied to know the students' activities during teaching and learning process, (2) Test was done to measure students' achievement, and (3) field note was done to obtain information about teacher, the students' activities and performance during the implementation of dictogloss technique. The finding of this study indicated that Dictogoss technique improved the students' listening skill. The result of the study showed that there was improvement of students' listeing skill by using dictogloss. Most students gradually gained good score at the end of each cycle. The score minimum mastery criterion-Kriteria Ketuntasan Minimal (KKM) of English lesson was 75 (seventy five). The mean score in the first cycle was 70.63. The mean score in the second cycle was 78.19. In addition, there was a positive response from the English teacher about implementing the action. In conclusion Dictogloss technique could improve students' listening skill in the second year of SMKN3 Sorong in the Academic year 2016/2017.
\end{abstract}

Keywords: Listening Skill, Dictogloss Technique

Abstrak: Mendengar adalah kemampuan dasar yang dibutuhkan untuk menguasai dan mendukung kemampuan lainnya seperti berbicara, membaca dan menulis. Tujuan penelitian ini adalah untuk mengetahui apakah penggunaan teknik dictogloss dapat meningkatkan kemampuan mendengarkan siswa SMKN 3 Sorong dikelas XI OD yang berjumlah 22 siswa. Penelitian ini adalah penelitian tindakan kelas yang dilakukan dalam 2 siklus. Teknik pengumpulan data diperoleh melalui (1) lembar observasi yang diterapkan untuk mengetahui kegiatan siswa selam proses belajar mengajar, (2) Tes objektif yang dilakukan untuk mengukur pencapaian siswa, dan (3) Catatan yang dilakukan untuk memperoleh informasi mengenai kegiatan dan ketrampilan siswa dalam mendengarkan dapat ditingkatkan dengan menggunakan teknik dictogloss. Seluruh siswa mendapatkan nilai yang bagus pada akhir siklus. Nilai ketuntasasn pada pelajaran Bhs Inggris adalah 75 (Tujuh Puluh Lima). Nilai rata-rata pada siklus 1 adalah 70.63. Nilai rata-rata siklus 2 adalah 78.19. Peningkatan ini merupakan hal yang positif bagi guruBhsInggris dalam menerapkan tindakan. Kesimpilannya Teknik Dictogloss dapat meningkatkan kemampuan siswa dalam mendengarkan pada siswa kelas XI OD SMK 3 Sorong Th Ajaran 2016/2017.

Kata Kunci: Kemampuan mendengar, teknik dictogloss, SMKN 3 Sorong 


\section{Pendahuluan}

Sebagai salah satu bahasa internasional, Bahasa Inggris berperan penting hampir di setiap aspek kehidupan. Bahasa Inggris telah menjadi bahasa asing wajib di Indonesia. Bahasa Inggris merupakan mata pelajaran yang sudah diajarkan sejak sekolah dasar hingga perguruan tinggi dan diujikan dalam ujian nasional untuk menentukan kelulusan siswa. Sebagai salah satul kemampuan penting dalam pembelajaran bahasa, mendengarkan atau listening berperan penting dalam komunikasi. Kemampuan ini mengharuskan pebelajar untuk menerima dan memahami informasi yang diterima (Ross: 2002). Listening merupakan sebuah kemampuan dasar yang sangat penting untuk dikuasai guna mendukung kemampuan lain seperti speaking, reading dan writing.

Mengajar listening di ruang kelas sangat berbeda dengan listening dalam kehidupan sehari-hari (Ur, 1998). Listening dalam kehidupan nyata mencakup beberapa situasi seperti: (1) Kita mendengarkan untuk tujuan dan informasi tertentu, (2) Kita membuat respon secepat mungkin atas apa yang kita dengar, (3) Kita melihat orang yang kita dengarkan, (4) terdapat beberapa petunjuk lingkungan dan visual terkait makna dari apa yang kita dengarkan, (5) sebagian besar discourse yang didengarkan terjadi secara spontan dan berbeda dari pembicaraan formal dalam hal kebisingan, koloqial yang digunakan dan karakter auditori.

Listening merupakan salah satu kemampuan berbahasa yang penting karena merupakan bentuk dasar pemerolehan bahasa. Hal ini dibuktikan oleh fakta bahwa bayi mulai memperoleh bahasa dengan mendengarkan suara disekelilingnya sebelum bayi tersebut mulai berbicara dan belajar menulis dan membaca. Krashen (dalam Arief dan Adnan, 2013: 51) menyatakan bahwa pemerolehan bahasa secara dominan dilakukan dengan menerima input yang dapat dipahami dan kemampuan mendengarkan merupakan komponen penting dalam memperoleh input bahasa yang dapat dipahami tersebut. Melalui mendengarkan, pebelajar bahasa menerima input lisan dan kemudian mereka belajar untuk meniru, memproduksi dan mempraktekkan bunyi kata, frasa dan kalimat dari bahasa sasaran. jika pendengar tidak dapat memahami materi listening atau input, komunikasi akan kacau. Seperti yang dikatakan oleh Nunan (2002: 239) bahwa tanpa memahami input di tingkat yang tepat, pembelajaran apapun tidak akan bisa dilakukan. Mendengarkan merupakan hal mendasar untuk berbicara. Pemahaman mendengarkan memiliki peran yang sangat penting dalam berkomunikasi.

SMKN 3 Sorong masih menerapkan kurikulum KTSP dimana pemahaman listening diajarkan di kelas X. berdasarkan pengamatan yang dilakukan peneliti di kelas XI SMKN 3 Sorong, sebagian besar siswa kesulitan dalam memahami listening. Sehingga, untuk membantu siswa meningkatkan kemampuan listening mereka dibutuhkan sebuah metode mengajar yang dapat mengatasi permasalahan tersebut.

Salah satu teknik yang ditawarkan dalam pemahaman listening adalah teknik Dictogloss. Teknik Dictogloss merupakan teknik mengajar klasik dimana pendengar diharuskan untuk merekonstruksi sebuah 
teks dengan mendengarkan dan mencatat kata kunci. Seperti yang telah dijelaskan bahwa masalah terbanyak yang dihadapi siswa adalah ketidakmampuan mereka dalam menentukan kata kunci yang harus diperhatikan dalam listening. Dalam penerapan teknik Dictogloss, pendengar diharuskan untuk memutuskan dan menangkap kata kunci dari audio yang mereka dengarkan. Oleh karena itu, peneliti yakni bahwa penggunaan teknik Dictogloss efektif untuk memecahkan masalah siswa dalam pemahaman listening.

Alasan mengapa teknik Dictogloss digunakan sebagai metode dalam mengajar yakni teknik ini efektif dalam memecahkan masalah siswa dalam pemahaman listening. Dalam penelitian ini, peneliti mencari tahu penerapan teknik Dictogloss dalam meningkatkan kemampuan listening siswa kelas XI SMKN 3 Sorong tahun pelajaran 2016/ 2017.

\section{Metode Penelitian}

\subsection{Desain Penelitian}

Penelitian ini menggunakan desain penelitian tindakan kelas. Penelitian tindakan kelas ini bertujuan untuk mengangkat permasalahan yang dihadapi siswa dan menentukan cara terbaik untuk menanganinya agar prestasi belajar Bahasa Inggris siswa meningkat. Model PTK yang digunakan adalah model Kemmis dan Mc Tagger (dalam Burns, 2010:7). PTK ini mencakup 4 tahapan pada tiap siklusnya yakni: perencanaan, tindakan, pengamatan dan refleksi.

\subsection{Subjek Penelitian}

Subjek dalam penelitian ini adalah siswa kelas XI OD teknik otomotif SMKN 3 Kota Sorong dengan jumlah siswa sebanyak Kelas XI 22 siswa.

\subsection{Teknik Pengumpulan Data}

Teknik pengumpulan data yang digunakan dalam penelitian ini adalah tes dan observasi. Tes digunakan untuk mengetahui hasil belajar siswa. Tes yang digunakan terdiri dari tes tertulis dan tes lisan. Sementara teknik observasi digunakan untuk memperoleh informasi tentang penerapan dictogloss.

\subsection{Teknik Analisis data}

Data dalam penelitian ini terdiri dari 2 jenis, yakni data kuantitatif dan kualitatif. Data kuantitatif berupa hasil tes siswa sedangkan data kualitatif berupa informasi terkait penerapan dictogloss dalam kelas Bahasa Inggris dan reaksi siswa terhadap proses pembelajaran.

\section{Hasil Penelitian dan Pembahasan}

Penerapan dictogloss dalam proses pembelajaran Bahasa Inggris terutama pembelajaran listening melalui penelitian tindakan kelas ini dilakukan dalam dua siklus. Masing-masing siklus dilakukan dalam 4 pertemuan yang mencakup pretest dan posttest. Masing-masing pertemuan terdiri dari 120 menit. 
Berdasarkan refleksi pada masing-masing siklus, terlihat bahwa kemampuan siswa dalam belajar Bahasa Inggris meningkat di setiap siklus. Hal ini menunjukkan bahwa siswa lebih termotivasi dan tertarik dalam pembelajaran Bahasa Inggris. Hal tersebut juga dibuktikan dengan persentase nilai siswa dalam tes oral sebesar $75 \%$ pada siklus I dan $85 \%$ pada siklus II. Nilai rata-rata pretest pada siklus I adalah 49,17 dan nilai posttest adalah 68,48. Sedangkan pada siklus II nilai pretest sebesar 65,74 dan posttest 80,43 . Nilai ketuntasan rata-rata pada masing-masing siklus juga menunjukkan peningkatan dari $13 \%$ menjadi $43 \%$ pada siklus I dan 34\% menjadi 95\% pada siklus II. Hasil tersebut menunjukkan bahwa strategi pembelajaran dictogloss secara efektif mampu meningkatkan kemampuan mendengarkan siswa kelas XI SMKN 3 Kota Sorong tahun ajaran 2016/2017.

Hasil penelitian menunjukkan bahwa penggunaakn teknik pembelajaran dictogloss dapat meningkatkan kemampuan mendengarkan siswa, keaktifan, minat dan prestasi siswa. Penerapan teknik dictogloss ini dapat memberikan kesempatan bagi siswa untuk mengetahui apa yang belum mereka ketahui dan bagaimana cara memperbaikinya. Siswa juga berkesempatan untuk meningkatkan kemampuan berbicara mereka dengan cara mengungkapkan pendapat dan bertanya.

\section{Simpulan dan Saran}

\subsection{Kesimpulan}

Setelah menganalisis data, peneliti menemukan bahwa hasil belajar siswa dalam listening skill meningkat dari siklus I hingga siklus II. Hal ini ditunjukkan dengan nilai rata-rata siswa pada tes listening siklus I sebesar 68,48 dan pada siklus II 80,43. Dengan demikian, dapat disimpulkan bahwa: sebelum dilakukan tindakan, siswa kesulitan dalam memahami teks listening yang diberikan oleh guru dan siswa tidak termotivasi untuk belajar sehingga mereka mendapatkan nilai rendahdalam memahami teks. Siswa juga merasa bosan dengan proses pembelajaran yang berlangsung.

Setelah diterapkan teknik dictogloss dalam pembelajaran listening pada siklus I diperoleh proses yang baik dalam setiap pertemuannya. Kemampuan siswa dalam menemukan informasi tertentu berdasarkan teknik dictogloss menunjukkan peningkatan yang baik. Kemampuan siswa dalam mengidentifikasi tujuan komunikatif teks dengan diterapkannya teknik dictogloss pada aktivitas mendengarkan pada siklus II meningkat cukup signifikan. Hal ini dapat disimpulkan bahwa teknik dictogloss dapat meningkatkan kemampuan mendengarkan siswa terutama dalam menentukan makna kata dan frasa, menentukan ide pokok, mencari informasi tertentu, dan mengidentifikasi tujuan komunikatif teks.

\subsection{Saran}

Berdasarkan kesimpulan penelitian, peneliti menyarankan beberapa hal berikut: 
1. Bagi guru, guru harus peka terhadap kebutuhan siswa. Teknik pengajaran dictogloss dapat digunakan sebagai alternatif bagi siswa yang memiliki masalah dalam pembelajaran Bahasa Inggris. Teknik ini mempermudah guru dalam memperbaiki kesalahan siswa. Teknik ini juga mempengaruhi ketertarikan siswa dan membuat mereka menikmati pembelajaran Bahasa Inggris.

2. Bagi siswa, siswa harus lebih aktif dalam proses pembelajaran. Mereka harus lebih aktif dalam bertanya tanpa rasa takut karena dengan bertanya proses pembelajaran akan lebih mudah. Siswa hendaknya tidak takut untuk memberikan pendapat karena dengan menyampaikan pendapat mereka dapat bertukar ide dan memperluas pengetahuan.

3. Bagi peneliti, diharapkan guru akan menggunakan metode terbaik dalam mengajar agar hasil yang diperoleh bisa maksimal terutama dalam proses pembelajaran Bahasa Inggris. Sementara bagi peneliti lain, penelitian ini dapat digunakan sebagai referensi tambahan untuk penelitian lebih lanjut dengan sampel yang berbeda.

\section{Daftar Pustaka}

Brown, H. Douglas. 2001. Teaching by Principles. An Interactive Approach to Language Pedagogy. New York: Pearson.

Dornyei, Zoltan. 2001. Motivation Strategies in the Language Strategies. United Kingdom: Cambridge University Press.

Harris, D. P. 1974. Testing English as a Second Language. TMH Edition. Boston: Pearson Education, Inc.

Oshima, and Houge, Ann.1991. Writing Academic English. New York. Adison WesleyLongman.

Swain, M. \&Lapkin, S. (1998). Interaction and Second Language Learning: Two Adolescent French Immersion Students Working Together. The Modern Language Journal, 82: 320-337.

Swain, M. \&Miccoli, L. S. ( 1994). Learning in a Content-Based,Collaboratively Structured Course. The Experience of an Adult ESL Learner. TESL Canada Journal 12 (1): 15-28.

Thornton, P. (1999). Reading Together.In Kluge, D. McGuire, S., Johnson, D. and Johnson, R. (Eds.), Cooperative Vol. 3, No. 1. English Language Teaching Learning (pp. 95-105). Japan: JALT Applied Materials.

Ur, P. (1998). Teaching Listening Comprehension. UK: Cambridge University Press.

Vasiljevic, Zorana. 2010. Dictogloss as an Interactive Method in Teaching Listening Comprehension to L2 Learners. Retrieved on May 25th, 2011 from http://www.ccsenet.org/journal/index.php/elt/article/view/5212.

Wajnryb, Ruth. 1990. Resource Books for Teachers: Grammar Dictation. Oxford: Oxford University Press 